\title{
Innovation, Imitation and Competitive Value Analysis
}

\author{
Margherita Corniani ${ }^{*}$
}

\begin{abstract}
The most widespread kind of innovation in global markets is incremental innovation, which modifies business processes, typically without visible manifestations outside the company. Incremental innovation is also applied to products, bringing changes to their characteristics, and/or impacting on the supply profile, with the aim of attracting customers and even of stealing them from competitors.

These incremental innovations are usually the result of imitation processes that are the effect of the application of passive and competitive value analysis. Value analysis implies the breakdown of processes, products and offers, looking for alternative solutions and improvements that are economically and competitively viable.
\end{abstract}

Keywords: Innovation; Imitation; Value Analysis; Global Markets; Competition

\section{Innovation and Imitation}

Innovating is considered one of the primary goals of the firm, and one that is necessary to guarantee business development in time (Schumpeter 1934, 1939). In particular, we can distinguish between product/process innovation, in other words innovation that modifies a product or process, and supply innovation, which affects overall supply. A traditional classification of innovation tends on the other hand to distinguish whether innovation 'comes from a laboratory' and is then imposed on the market (push innovation), or whether it is determined by a 'market request' (pull innovation), and is therefore offered by companies as a response to specific needs observed in demand (Levitt 1962).

A different analysis of innovation distinguishes between path-breaking innovation (breaktrought) and incremental innovation, based on the degree of 'novelty' and the reach of an innovation (Abernathy, Utterback 1978; Tushman, Anderson 1986), or even between continuous and discontinuous innovation (Porter 1986).

However, implicitly, in spite of the fact that innovation and imitation are closely linked processes, in Western countries attention has tended to be focused primarily

\footnotetext{
* Associate Professor of Management, University of Milan-Bicocca (margherita.corniani@unimib.it) 
on innovation, overlooking the value of imitation. Imitation has often been considered on a par with copying, attributing negative connotations to it, thus determining a hierarchy in which innovation is a virtuous process, whereas imitation/copying takes second place, often being considered a parasitic process that exploits other people's investments and, as such, must be prevented in economic systems by the implementation of suitable systems, such as patents, to regulate and protect innovation (Mansfield et al. 1981; Bessen, Maskin, 2000).

The criterion of imitation and its incessant reproduction over time is characterised by many aspects of some of the older Oriental cultures, including the Chinese.

In particular, Chinese script is based on the capacity to reproduce complex signs, various combinations of which produce a huge number of characters. Each character presupposes a specific way of drawing the signs that it comprises and is all the more perfect the better the person executing them has memorised them and has practised drawing the character in time, in other words imitating it an infinity of times.

The principle of continuous improvement -by repeating the same process with the purpose of modifying its phases progressively but continuously- is also implicit in Japanese culture, where the kaizen principles (kai which means 'change' and zen which means 'for the best') developed immediately after the war, underpinning the incessant process of improvement that Japanese companies adopted to reach and overtake their American competitors, which were considered the benchmark to be reached and overtaken.

"Kaizen originated in Japan in 1950 when the management and government acknowledge that there was a problem in the current confrontational management system and a pending labour shortage. Japan sought to resolve this problem in cooperation with the workforce. The groundwork had been laid in the labour contracts championed by the government and was taken up by most major companies, which introduced lifetime employment and guidelines for distribution of benefits for the development of the company. This contract remains the background for all Kaizen activities providing the necessary security to ensure confidence in the workforce. First, it was been introduced and applied by Imai in 1986 to improve efficiency, productivity and competitiveness in Toyota, a Japanese carmaker company in the wake of increasing competition and the pressure of globalisation. Since then, Kaizen has become a part of the Japanese manufacturing system and has contributed enormously to the manufacturing success" (Singh, Singh 2009).

In the West, but also in the East, the principle of copying has always been one of the founding bricks of learning. However, because one can progress from simple copying to a process of marginal imitation, which can add, remove or modify some elements of the original object, it is necessary to operate methodically. The wellknown concept of 'value analysis', which was codified in the Second World War by Lawrence Miles with Jerry Leftow and Harry Erlicher, all engineers at General Electric, must be seen in this context. 


\subsection{Innovation and Imitation of Products/Processes}

\subsubsection{Innovation of Products/Processes}

Firms tend to spend more on development activities (design, construction and testing of prototypes and pilot systems) rather than on research (development, testing and definition of laws and models).

$\square$ "We construct and operate ... systems based on prior experiences, and we innovate them by open loop feedback. That is, we look at the system and ask ourselves 'How can we do it better?' We then make some change, and see if our expectation of 'better' is fulfilled ... This cyclic, open loop feedback process has also been called 'learning-bydoing', 'learning by using', 'trial and error', and even 'muddling through'. Development processes can be quite rational or largely intuitive, but by whatever name, and however rational or intuitive, it is an important research process ... providing means of improving systems which lie beyond our ability to operate or innovate via analysis or computation" (Patel, Pavitt 1995).

The context of R\&D activities is closely linked to the potential for innovation and comprises very different activities. Research activities are one thing, while development activities are another. Both types of activity are an essential part of processes to generate path-breaking innovation, in the sense that, to achieve innovation that can really break with existing patterns it is necessary both to invest in research and to discover/invent 'something' new (a molecule, product, process, etc.), and to invest massively in the development of the innovation, so that it can be successfully exploited, incorporating it into company products or processes.

However, this second area of investment, which addresses the development of research products is one of the largest expense items for the realisation of novelties. Development processes address the performance of all the checks, tests and changes necessary to enable the effective economic use of the invention by companies. But development processes can regard any 'object', whether this is an innovation or a product/process existing in the company.

Development therefore represents the 'second stage' for the exploitation of the research and is complementary to it, an indispensable investment to complete the value of the research undertaken. So it is clear why we usually refer jointly to research and development, and also why, although development can generate huge additional costs for companies, its execution is not questioned, but represents the completion of the research and the enhancement of the resources committed.

Development activities can therefore be undertaken even starting from molecules, products or processes that are not at all new for the business or for the market, but have existed for some time. The principle of learning founded on experience, trial and error, lies at the basis of forms of innovation and imitation that do not aim to create something really new for the company or the market, but simply attempt to improve existing products or processes, to render them economically more interesting. 
This economic appeal regards the factors of effectiveness and of efficiency. On one hand it is a question of achieving greater effectiveness, in other words better achievement of the goal. In the case of a product, one seeks solutions so that it can perform its required purpose better (for example, a saucepan that distributes heat more uniformly over the entire surface and maintains it for longer). Similarly, in the case of a process, it is a question of identifying different stages to obtain an identical result (for example, a manufacturing process without secondary effects or wastage, or one that minimises the presence of sub-products). On the other hand, it is a question of striving for efficiency and solutions which, having achieved their set purpose, can keep the consumption of resources to a minimum. Evidently, both objectives can be perfected in time and, for this reason, there is always plenty of room for manoeuvre in the search for improvements and adjustments to products and processes.

\subsubsection{Product/Process Imitation}

The principle of imitation is one aspect of the constant striving for continuous improvements to the effectiveness and efficiency of products and processes. Imitation incorporates both simple copying processes (given a product or process, the intention is to copy it to create an identical one) and 'marginal' or 'innovative' imitation processes (given a product or process, the intention is to copy it, gradually improving its effectiveness and efficiency, and creating something that is new, at least in part). Copying which, as we know, lies behind every learning process, therefore produces two important immediate results: the reproduction of a product that is identical (or very similar) to the product copied and its degeneration, the result of counterfeiting. Whereas in the first case the person reproducing does not intend to hide the fact that the product or process performed is a reproduction of an original asset or process, in the case of counterfeiting, there is an implicit intention to trick a third party, hiding the true nature of the process in order to realise significant margins. Both cases can involve aspects such as the quality of the process or materials, etc., but the problem might not present itself in these terms. Even in the context of copying and of counterfeiting itself, there can be various levels of 'quality'.

It is possible to find products that are deliberately copied to maintain the quality specifics of the originals (for example non-original parts produced by the same manufacturers as the original parts, with the same materials and procedures), but sold at lower prices because they are not subject to the payment of specific royalties.

$\square$ This is what happens with numerous industrial products (machinery, etc.) for which some manufacturers outsource all or part of their output, selling their patents, machinery and the know-how to produce their products to less technologically advanced partners (and therefore with less expensive processes, for example in China, India and other countries in the Far East) (Minagawa et al. 2007).

A contract to manufacture under licence envisages the authorisation to mark a specific number of products with the trademark of the owner of the patent and the process. However, very often, the licensed manufacturer is able to produce and market larger quantities of the product in question but is not authorised to do so. As a result, in many cases, the licensee undertakes other productions (using the same 
process and with the same quality) turning out and selling the same products at lower prices, on different markets for example.

In other cases the sub-contractor chooses to partially copy the product or the spare parts with a higher rotation and a larger margin, only apparently making them identical to the originals, but in fact saving on the processes and materials, and inferring that these products are exactly like the originals or even marking them with the original trademark.

Naturally, following a theoretical continuum (Figure 1), which develops gradually from licensed production that respects specifications perfectly to total counterfeiting, there is a broad scale of variables where quality, price and counterfeiting are concerned. The management and control of these variables are extremely complex, on the part of both the firms granting the right to manufacture under licence (OEMOriginal Equipment Manufacturer) and of the licensee companies (Trott, Hoecht 2007).

Figure 1: Production under Licence, Counterfeiting and Imitation

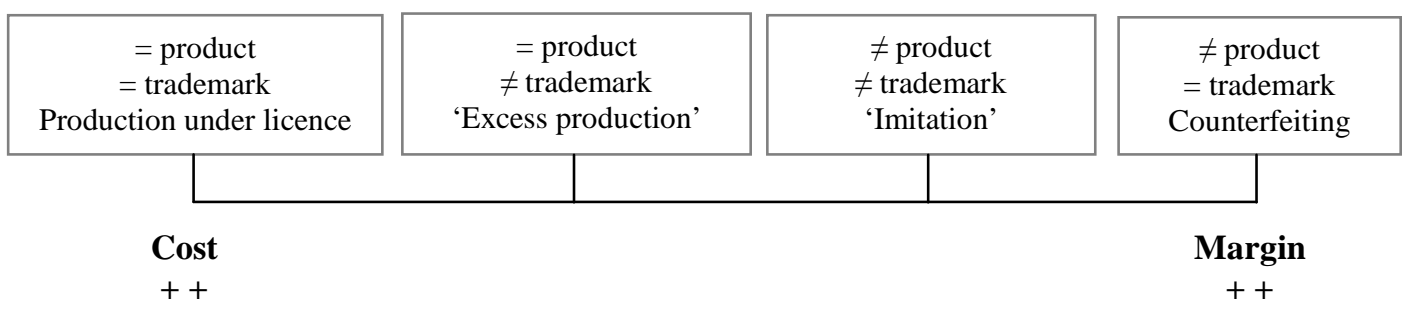

As the situations described above all reveal, the potential for innovation remains limited because it requires huge investment and is generally the work of only a few companies with the necessary resources. The potential for imitation on the other hand is practically infinite and may be realised by following various guidelines that range from copying (and counterfeiting as a degeneration of copying) to 'marginal' imitation, right down to forms that can be considered incremental innovations or, at times, even straightforward innovation. The wide variety of imitation processes makes this phenomenon interesting from an economical viewpoint, in relation to the result achievable and the different cost levels that can be sustained, i.e. in relation to the margins that are potentially obtainable from different combinations of imitation and improvement.

\subsection{Innovations and Supply Imitations}

The concept of novelty is very broad and depends both on the intrinsic characteristics of a product or process that might already exist (i.e. already experimented by someone) or be entirely new, and on the marketing method used for the product, which may be new for a market or for specific customer brackets and not for the company that markets it. It is also possible to have products that are new for the company but not for the market where the company operates. In other words, there is space for novelties that are not necessarily or only linked to the product or to its manufacturing dimension (process, materials, etc.), but refer exclusively to the commercial area and, more generally, to the marketing area. 
Similarly, imitations can also refer to the commercial and marketing areas, both in the form of copying (business and/or commercial formulae that are entirely copied), and in 'marginal' forms, by which a company takes its inspiration from another company's action to improve the solution offered, and achieves competitive advantages that may even be higher than those of the company that introduced the commercial innovation.

$\square$ Like many restaurant chains in the USA, McDonald's copied the White Castle formula proposed by its founder Walter Anderson, who was the first to launch a chain of fast food restaurants at standard prices in 1921. The McDonald's formula was copied extensively by numerous other restaurateurs who, over the years, took it as the example to follow to define their own commercial proposals, introducing breakfast, healthy eating, etc. (Shenkar 2010).

In fact the mechanism of action and competitive reaction and leader-follower dynamics underpin copying and imitation processes, with the result that more competitive corporations invest explicitly in actions to keep their attention oriented to competitors (market-driven management), even activating functions that specifically address the monitoring of competitive action (competitive intelligence) (Corniani 2004).

Imitation mechanisms that derive from competitive intelligence activities therefore do not only regard the technical-manufacturing sphere of products or manufacturing processes, but also and above all that of supply solutions. So there are inventions and imitations which, as in the cases of commercial imitation mentioned above, do not originate from the area of capital spending on research, nor from that of development activities (R\&D), but rather from other areas such as financial, commercial or marketing activities, and they lead companies to offer innovative products or solutions on the market (Gnecchi, Corniani 2003).

On the other hand, supply innovations/imitations regard the supply profile and not the products that comprise it. These are innovations or imitations that do not present a new product, with new basic or accessory features, but products that are already widespread and familiar on the market, for which the company manages to invent or imitate a supply combination that presents itself as innovative in the customer's eyes (demand bubble) (Corniani 2005). For example, sales promotions may constitute a tool of supply innovation, because they modify the profile of a supply in the eyes of the clientele, making it more attractive and certainly innovative compared to others on the market. Promotion, like bundling, can therefore help to modify the characteristics of a corporate supply without having any impact on the characteristics of the manufacturing processes or assembly of the products involved. However, the supply innovation generates significant modifications in the provisioning and marketing processes, because it modifies the natural product rotation trend. These supply innovations usually require companies to manage provisioning, manufacturing, assembly and marketing flows that are accelerated or concentrated in particular moments, with consequent changes to the processes of the entire supply chain. In other words they are innovations that apparently only have an impact with regard to the final clientele and which, in fact, demand from companies a complex capacity to adapt to new ways of managing inbound and outbound supply flows throughout the entire network of relationships. 
Even supply innovations are not always genuine innovations but, more often, simple imitations of solutions that have already been developed by other companies, both competitors and in other sectors. In this sense, imitation is therefore continuous, and every company knows, as soon as it innovates, proposing a new supply profile, that its competitors will do the same, in a very short space of time; in fact, the faster the reaction of demand to supply proposals the shorter this time will be.

\begin{abstract}
$\square$ "In spite of the extraordinary outpouring of totally and partially new products and new ways of doing things that we are witnessing today, by far the greatest flow of newness is not innovation at all. Rather, it is imitation. A simple look around us will, I think, quickly show that imitation is not only more abundant than innovation, but actually a much more prevalent road to business growth and profits. IBM got into computers as an imitator; Texas Instruments, into transistors as an imitator; Holiday Inns, into motels as an imitator; RCA, into television as an imitator; Lytton, into savings and loans as an imitator; and Playboy, into both its major fields (publishing and entertainment) as an imitator. In addition, though on a lesser scale, we see every day that private brands are strictly imitative, as are most toys and new brands of packaged foods. In fact, imitation is endemic. Innovation is scarce" (Levitt 1966).
\end{abstract}

Of course, supply innovations/imitations can combine both product variants (for example radical or incremental innovations, i.e. imitations that improve some aspect that is not marginal for demand), and variants that are linked solely to the supply profile. The majority of new offers of high-tech products on consumer markets should be seen from this perspective. As a result, today it is possible to observe radical innovations (for example, the introduction of digital technologies in TV), followed by gradual processes of improvement to product characteristics at very competitive prices (for example, where LCD televisions in particular are concerned, larger and flatter screens, with wider viewing angles). These are not inferior to other products that perform less well but are still present on the market (a previous model from the same brand, a similar model from the competition). Another well-known example of this advanced combination of product innovations and supply profile can be found in the smartphone market, where well-known manufacturers (Apple, Samsung, Blackberry, etc.) continue to offer on the market a range of path-breaking innovations and incremental innovations or, better still, innovations that improve their own products and those of the competition. These manufacturers achieve high sales volumes as a result of important partnerships with suppliers of mobile telephony, which incorporate the 'new' smartphones into supply profiles that are progressively more competitive and attractive for the clientele. The overall value of this supply is perceived as highly innovative by the customer, without there actually being any significant product innovation (an imitation that improves an existing product, for example with a new version of an operating system, a more reactive touch screen, a higher definition video camera, etc.).

The recognised effect of these partnerships and continuous competitive imitation in these industries is so overpowering that it generates a striking volumes of sales of the new products by a few leading operators on the market. They follow each other, 
alternating in the launch of new, better performing products, in a continuous process of development and exploitation of the market.

\section{Value Analysis, Imitation and Global Markets}

Imitation processes obviously presuppose that there are some 'objects' that are worth imitating. In this sense, the guiding principle that Sharp attributes to its founder, Tokuji Hayakawa, is emblematic: "Make products that others want to imitate" (www.sharpusa.com). The outstanding Japanese businessman, who grounded his company's success on the capacity to imitate existing products on a vast scale, had grasped the first key aspect of the phenomena of innovation and imitation. In other words he identified in imitation both the test of an innovation's effectiveness (if an innovation is good, everyone will try to imitate it) and, more opportunely, the development factor of the innovation.

Imitation (me-too products) opens up the market for innovative products. In other words, it is not enough for there to be a businessman-innovator, the market also has to include imitators, companies that contribute with the innovator to the creation of the market and to its expansion. "Each solitary innovator sparks a wave of eager imitators. By the time a so-called 'new' product reaches widespread visibility, it has usually been on the market for some time. Its visibility is less a consequence of its actual or temporal newness than it is of the number of its strident imitators. The newness of which consumers become aware is generally imitative and tardy newness, not innovative and timely newness" (Levitt 1966).

The presence on the market of a leading company and of other imitator companies contributes to the development of global demand for a particular class of product and, in this sense, enables all offering companies to acquire market share in a broader global market. Becoming a single innovative manufacturer who supports the burden of research, development and the creation of the market for its own innovative products may be too arduous a task for a single corporation to undertake on some markets. There is therefore space for competitors who work together to create the demand necessary to incorporate and absorb innovations.

On the other hand, if they appear to underpin a significant market potential, innovations forcibly attract imitators. The point lies in the form of imitation that is put in place: copying (or even counterfeiting) or a marginal imitation. This second form of imitation constitutes the traditional process of improvement that underpins many learning phenomena which are founded on imitation and, above all, on the reiteration of imitation.

The first result of value analysis as applied by Miles made it possible to develop certain production lines, in spite of the wartime restrictions on the supply of a number of materials and components. However, because it was prompted by conditions of wartime restrictions, the process also had the secondary effect of achieving important cost economies. Because it was oriented at replacing quality products and productions (which were therefore difficult to obtain during the war) with lower quality products and productions that were therefore less expensive, it could be used to achieve economies in manufacturing processes. 


\begin{abstract}
$\square$ During the War, Miles had to tackle the problem of performing manufacturing processes without skilled manpower, and with a paucity of materials and components, which were scarce or inaccessible because of wartime restrictions. With his team of engineers, Miles tried to find a solution to the problem facing him, process by process and component by component, developing a procedure founded on an analysis of the value of each element, in relation to the process that it was a part of or in relation to the product that comprised it.
\end{abstract}

Value analysis specifically offers a 'method' to regularly proceed toward improved imitation.

This analysis entails breaking each product down and verifying the usefulness of each component in relation to the overall practicality of the product itself. The process then entails searching for possible alternatives to each component, both by checking replacement products and by assessing the possibility of making the same component using different materials, forms and procedures.

Value analysis is based on three main steps: 1) identification of the function, 2) assessment of the function and comparison with other alternatives in economic terms, 3) examination of valid alternatives to develop (Miles 1962).

\title{
2.1 Passive Value Analysis
}

Value analysis has been so effective that it itself became a process disseminated in the company environment, to be employed in the search for economies in products and processes. As a result it spread all over the USA and from there to the rest of the world, acquiring various names as it did so, including value engineering, value methodology and function analysis. It was structured in specific stages, in order to achieve two main results: first of all, to save resources, looking for the most efficient solutions while achieving the same result in terms of the function of the product developed; but also, secondly, to verify the potential to improve the function of the products analysed, in other words, a greater efficacy. All in all, this analysis therefore addresses the creation of greater value for the products developed.

The key aspect of value analysis is therefore the 'value' of the existing product or process, which must be considered valid in the competitive context and deemed worthy of the investment and the effort to achieve dedicated improvement. This improvement naturally regards both the result (i.e. the product or process, which are 'improved' by value analysis, in terms of the functions that they make it possible to achieve - effectiveness of the value analysis process), and the way in which this improvement is achieved (i.e. the procedure that leads to improvement is also improved - efficiency of the value analysis).

However, the main aim of value analysis is, first and foremost, the achievement of cost economies. So much so that Miles himself fought for a long time against the "lower cost means lower quality" principle, explaining that his method was designed to pursue "better cost and better quality" simultaneously (Miles 1962). From this perspective, value analysis is a process that is applied to the products or processes that a company already produces, with the aim of breaking them down so much and rationalising each component used in each operation performed to such an extent that it becomes possible to achieve savings. Research into every element of a product or every stage of a process, or a possible alternative that is less expensive but equally 
effective, or even more effective, is therefore the central nucleus of value analysis and, because it is performed passively, i.e. on the products and processes owned by a company, all the elements necessary to execute it are available in the company computer system.

\subsection{Competitive Value Analysis}

For a certain amount of time the birth of value analysis in emergency conditions, like those of the war years, limited its functions to the systematic search for savings inside the company. However, the rapid changes in the competitive dynamics of numerous markets, starting from the second world war, have prompted companies to focus first on demand and then on the competition. In other words, value analysis, which is now regularly undertaken for the main company products and processes, constantly striving for efficiency, has become the tool to apply to the products of third parties, thus creating so-called competitive value analysis.

With competitive value analysis, companies try, first and foremost, to understand fully how competitive products function in order to grasp ideas and stimuli to use and replicate in their own products and processes. Of course, the great difference between the execution of value analysis on company products and on those of the competition lies in the fact that, in the first case, information about production stages, processes and materials, etc. is completely familiar and accessible in the company, whereas in the case of competitive analysis, it is necessary to break competitors' products down, estimating whatever is not directly evident from material analysis of the products. One technical note applied to develop competitive value analysis is reverse engineering (or reverse $R \& D$ ), which entails purchasing a competitive product and analysing it in detail by implementing a series of successive stages and processes, in order to understand the product's overall function, the composition of the various component elements and the contribution that each element makes to the overall function, and to deduce the means of production and assembly (Otto, Wood 1998).

On today's global markets, passive value analysis lies at the base of any project to develop new products or to reorganise manufacturing processes linked to existing processes, as part of the striving for constant savings and cost reductions, primarily associated with manufacturing processes. Decisions to de-localise manufacturing activities and the search for global economies of scales (Crompton, Lesourd 2004; Brondoni 2008) but also the dynamic location of manufacturing plants, should be seen from this perspective (Garbelli 2005).

The value analysis, therefore, offers companies a coded 'method' to direct company efforts in search of a higher value of products and offerings. The outcome of this process, however, depends on its implementation, concerning:

- frequency of activation;

- dedicated resources.

In global markets, in fact, where competition dynamics are accelerated, value analysis is inserted in $R \& D$ activities by competitive firms and continuously activated over time, devoting significant resources. An example of a firm focus on these processes can be observed in some industries that have reached important results in their processes of innovation and imitation: it is the case of hybrid engines for Toyota (Toyota is now the world leader in sales of hybrid vehicles); of the industry of memories of LG (LG is the world leader in the production of DRam) and 
of smartphones from Samsung (Samsung is contending with Apple the world records in the sale of smartphones).

\section{Emerging Issues: Competitive Value Analysis and the Corporate Relations System}

However, competitive value analysis is not limited to the 'analysis' of products or supply solutions developed by competitors, but actually constitutes a real marketdriven process. By this process the company analyses and tries to replicate in the best possible way the complex system of relations that trigger competitor(s) to develop that specific production or that product solution. It is a question of examining in detail the conditions of alliances, partnerships, etc. on which a company bases its capacity for innovation, imitation and rapid action and competitive reaction. It is no coincidence that, in the field of mobile telephony, smartphones are manufactured by the same manufacturers all over the world, for all competitors. However, all the producers of smartphones do not approach the processes of innovation and imitation of their components in the same way.

$\square$ The importance of adopting a typically market-driven outside-in approach in this context is particularly evident in the case of Samsung, the Korean colossus, which reveals an exceptional readiness to welcome innovative ideas, products, etc. and to develop them internally, incorporating them into new proposals that are competitive on the market. The home page of the company's Internet site in all countries of the world states that "Samsung Electronics is looking for potential world-class partners with innovative and distinctive technologies for collaboration and creating new business opportunities", and asks anyone who has an idea or product that he wishes to submit to Samsung to activate the link, by a simple click.

What is more, for Samsung, capital spending on $R \& D$ is a crucial aspect of its business, as we can see by the number of Samsung branches all over the world - all fully owned by Samsung - that are dedicated to this specific activity (Samsung Electronics Annual Report 2011).

The capacity to imitate products and processes, including managerial processes of the creation and operation of key business relations for a company, is therefore the central nucleus of competitive value analysis and certainly of the most effective imitation policies. In fact, on global markets, most technologies can be, and are, rapidly imitated, while the system of partnerships that makes this imitation possible (from the network information system to the capacity to acquire, process and disseminate information; from research and development systems that can respond rapidly, to lean, flexible manufacturing systems; from financial relations that can sustain products on a global scale, to the presence of commercial relations to really be present on outlet markets) is, on the other hand, the one resource in short supply. This overall capacity depends to a great extent on the company's culture, in other words, on its readiness to open up to these relationship possibilities and, above all, to welcome the dynamism that this generates and the opportunity/need to share even 
crucial information with one's partners, as an aspect of network development. If it is already difficult to know how to set up a system of relations that is effective and efficient in competitive terms, it is even more difficult to imitate this system, having learned it from the competition.

Value analysis, which employs techniques like reverse engineering which have been codified and applied over the years, has therefore shown that it is a way of effectively achieving the savings and improvements that are characteristic of passive and competitive imitation. However, as all the scholars and technicians who have examined the issue of innovation/imitation and the spread of specific implementation techniques for more than 50 years have amply demonstrated, innovation presupposes precise investment and clear intentions in research and subsequent development, just as imitation also needs intentionally activated procedures. "Imitation is not just something which even the biggest, best managed, most resourceful company will, by force of competitive circumstances, have to be involved in; it is something it will have to practice as a carefully developed strategy" (Levitt 1966).

In fact, imitation processes in the global markets lead businesses to tackle numerous strategic choices that take the form of alternative specifications in terms of:

- action times;

- costs to meet;

- partners to involve.

These choices, however, which are strategic both on local markets and on global ones, are particularly difficult to perform on global markets for several reasons:

- in global markets there are no local protecting boundaries. Any decision does not impact just in a single local area, but ranges in an open market where competitors are large, with a big competitive potential, and able to react on a very large scale;

- firm decisions imply high costs and revenues potentials and ask companies to manage complex distributed networks. This means to coordinate and exploit economies of size and location of multiple supply systems, production units distributed in global and national sales organizations (Canegrati 2009), research units heterogeneous and geographically dispersed, and dynamic development organizations. All this must also be realized using various forms of partnerships and alliances, (equity and non-equity), made with suppliers, customers and, more and more, also with competitors.

In particular, time is a crucial variable in imitation processes. Imitating manufacturers can often prove to be 'co-competitors' in the creation of market demand for the innovating company. However, if these competitors are to choose to imitate, contributing to the development of the market itself, then the new entrants need to have sufficient time to exploit the capital spending undertaken for the imitation. An imitator could reduce the risk of choosing the object to imitate if he waited to see which innovations were successful on the market, but in this case, he would risk 'missing the train' where the exploitable market potential is concerned. At the same time, the decision to imitate an innovation before its market success is clear, is itself a risk that depends on the potential for failure of that imitation (Levitt 1966).

In spite of this, the rapid succession of competitive actions and reactions typical of global markets highlights the crucial element of the imitation time, which becomes the critical variable to be minimised in comparison to the competition. However, this orientation finds a significant trade-off in costs: shorter imitation times, i.e. less time to invest in research and development, raise the cost of these activities (Graves 1989). Shorter research and development times can mean performing stages in parallel 
rather than in sequence, or they can speed up some stages by the joint action of several operators, etc. so that companies dedicate more human and financial resources to research and development processes.

For this reason too, i.e. to reach the market sooner, with imitations that perform better in terms of economic and competitive results (Cohen et al. 1996), global firms tend to enter into specific partnerships (with companies located up- or downstream of the supply chain or even with competitors) to reduce the competitive dynamism and to exploit the synergies of joint action. As a result, research and development times, costs and risks can be shared.

However, the capacity to identify the best partners and to invest the appropriate resources in these partnerships is a key skill for competitiveness on the global markets. The choice of the 'objects' to imitate and the strategic solutions on which to target the resources for imitation (which partner, when, which market) demands that companies must be able to activate appropriate outside-in capabilities that are founded on the development of suitable market-driven information systems (Sciarelli 2009; Tesfaye, Nguyen 2012).

$\square$ The experience of Kodak, world leader in the field of analogical photography, which declared bankruptcy in January 2012, is emblematic in this context. From 1993 Kodak developed partnerships and acquisitions in the fields of printed photography (film and paper) and of digital photography. However, Kodak targeted the major part of its investment in these innovative partnerships to the business that it was most familiar with, printed photography. "In the period 19932003, Kodak's type of response to the emergence of the digital technology is to adopt the innovation by playing both games at once. On the one hand, the company tried to make the traditional film-based business more attractive by investing more in it and utilising the digital technology to add more value into it. On the other hand, the new technology was also invested in, but mostly in what the company used to be familiar with in the film-based era. This pattern of investment remained even in the next period starting 2004. Thus, Kodak has hardly been said to ever embrace the new technology completely in the sense that the company has invested in it with a new mindset different from the one the company had in the context of the film-based technology" (Tesfaye, Nguyen 2012).

The experience of Kodak highlights how the ability to remain competitive on a market depends not only on the absolute size of the company, or on its competitive market position, but rather resides in the activation of processes that induce the change. This objective can be achieved by focusing on specific strategic choices, and dedicating defined resources to the exploration of potential areas of growth through imitation and development activities; that is, without standing on achieved positions which, in global markets, are easily imitated.

The competitive value analysis processes, provide global and market-driven companies with a set of 'techniques' but, above all, with a rule to address activities that may allow:

- the generation of imitations in the short term; 
- the likelihood of detecting potential imitations, able to reduce costs and develop revenues by selling competitive products and offers;

- the maintenance or the improvement of market positions;

- the development of business relationships, strong and able to activate over time new and continuous competitive imitation processes.

\section{Bibliography}

Abernathy William J., Utterback James M. (1978) Patterns of Innovation in Industry, Technology Review, vol. 80, n. 7, June-July, pp. 40-47.

Agarwal Rasjshree, Gort Michael (2001) First-Mover Advantage and the Speed of Competitive Entry, 1887-1986, Journal of Law and Economics, vol. 44, n. 1, pp. 161-177.

Bessen James, Maskin Eric (2000) Sequential Innovation, Patents and Imitation, Working Paper n. 00-01, January, MIT-Dep. of Economics, Cambridge, MA.

Brondoni Silvio M. (2010) Market-Driven Management, mercati globali e spazio competitivo d'impresa, in S.M. Brondoni, Market-Driven Management. Corporate Governance e spazio competitivo d'impresa, Giappichelli, Torino.

Brondoni Silvio M., Corniani Margherita (2012) Politiche di networking e modelli di sviluppo delle città knowledge production oriented, EyesReg-Giornale di Scienze Regionali, vol. 2, n. 2.

Brondoni Silvio M. (2008) Market-Driven Management, Competitive Space and Global Networks, Symphonya. Emerging Issues in Management (symphonya.unimib.it), n. 1, pp. 14-27.

http://dx.doi.org/10.4468/2008.1.02brondoni

Canegrati Tino (2009) Global Account Management for Sales Organization in Multinational Companies, Symphonya. Emerging Issues in Management (symphonya.unimib.it), n. 1, pp. 40-48 http://dx.doi.org/10.4468/2009.1.04canegrati

Carneiro Alberto (2000) How Does Knowledge Management Influence Innovation and Competitiveness?, Journal of Knowledge Management, 4, 2, 87-98. http://dx.doi.org/10.1108/13673270010372242

Cohen Morris A., Eliasberg Jehoshua Ho Teck-Hua (1996) New Product Development: The Performance and Time-to-Market Tradeoff, Management Science, 42, 2, 173-186.

http://dx.doi.org/10.1287/mnsc

Cohen Wesley M., Levinthal Daniel A. (1989) Empirical Studies of Innovation and Market Structures, in Richard Schmalensee, Robert Willig (eds.) Handbook of Industrial Organisation, Elsevier, Amsterdam.

Corniani Margherita (2004) Competitive Intelligence e Organizzazioni Market-Driven, in S.M. Brondoni (ed.) Il sistema delle risorse immateriali: cultura d'impresa, sistema informativo e patrimonio di marca, Giappichelli, Torino.

Corniani Margherita (2005) Market, Demand Segments and Demand Bubbles, Symphonya. Emerging Issues in Management (symphonya.unimib.it), 2, 13-30.

http://dx.doi.org/10.4468/2005.2.02corniani

Crompton Paul, Lesourd Jean-Baptiste (2004), Economies of Scale in Global Iron-Making, Resources Policy, vol. 33, n. 2, pp. 74-82.

http://dx.doi.org/10.1016/j.resourpol.2007.10.005

Darroch Jenny (2005) Knowledge Management, Innovation and Firm Performance, Journal of Knowledge Management, vol. 9, n. 3, pp. 101-115.

http://dx.doi.org/10.1108/13673270510602809

Garbelli Maria Emilia (2005) Product Differentiation Costs and Global Competition, Symphonya. Emerging Issues in Management (symphonya.unimib.it), n. 1, pp. 66-86.

http://dx.doi.org/10.4468/2005.1.06garbelli 
Gnecchi Flavio, Corniani Margherita (2003) Demand Bubbles, Virtual Communities and Market Potential, Symphonya. Emerging Issues in Management (symphonya.unimib.it), n. 2, pp. 34-50. http://dx.doi.org/10.4468/2003.2.04gnecchi.corniani

Graves Samuel B. (1989), The time-cost tradeoff in research and development: A review, Engineering Costs and Production Economics, vol. 16, n. 1, pp. 1-9.

http://dx.doi.org/10.1016/0167-188X(89)90011-6

Griffin Abbie, Hauser John R. (1993) The Voice of the Customer, Marketing Science, vol. 12, n. 1, pp. 1-27.

Griffin Abbie, Hauser John R. (1992) Patterns of Communication Among Marketing, Engineering, and Manufacturing - A Comparison between Two New Product Teams, Management Science, vol. 38, n. 3, (March), pp. 360-373.

Griffin Abbie, Hauser John R. (1996) Integrating Mechanisms for Marketing and R\&D, Journal of Product Innovation Management, vol. 13, n. 3, May, pp. 191-215.

Hauser John R., Zettelmeyer Florian (1997) Metrics to Evaluate R, D \& E, Research Technology Management, vol. 40, n. 4, July-August, pp. 32-38.

Hauser John R., Simester Dunkan I., Wernerfelt Birger (1996) Internal Customers and Internal Suppliers, Journal of Marketing Research, vol. 33, n. 3, August, pp. 268-280.

Ingle Kathryn A. (1994) Reverse Engineering, McGraw-Hill, New York.

Kim Linsu (1998) Crisis Construction and Organizational Learning: Capability Building in Catching-Up at Hyunday, Organization Science, vol. 9, n. 4, pp. 506-521.

Kim W. Chan, Mauborgne Renée (1999) Creating New Market Space: A Systematic Approach to Value Innovation Can Help Companies Break Free From the Competitive Pack, Harvard Business Review, January-February, pp. 83-93.

Les Earnest (2011) The First Three Spelling Checkers, Stanford University, http://www.stanford.edu/ learnest/spelling.pdf.

Levitt Theodore (1962) Innovation in Marketing: New Perspectives for Profit and Growth, McGraw-Hill, New York.

Levitt Theodore (1966) Innovative Imitation, Harvard Business Review, September-October.

Mansfield Edwin, Schwartz Mark, Wagner Samuel (1981) Imitation Costs and Patents: An Empirical Study, The Economic Journal, vol. 91, n. 364, December, pp. 907-918.

Miles Lawrence D. (1961), Techniques of Value Analysis and Engineering, Mc-Graw Hill, New York.

Miles Lawrence D. (1962), Techniques of Value Analysis and Engineering, Discorso presentato al 6th Annual Inland Empire Quality Control Conference, January 27.

Minagawa Tetsuya Jr., Trott Paul, Hoecht Andreas (2007) Counterfeit, Imitation, Reverse Engineering and Learning: Reflection from Chinese Manufacturing Firms, $R \& D$ Management, vol. 37 , n. 5, pp. 455-467.

OECD Science, Technology and Industry Scoreboard 2011, Sep 2011, ISBN: 9789264105256 (HTML); 9789264111653 (print).

http://dx.doi.org/10.1787/sti_scoreboard-2011-en

Olsen Veflen N. (2006) Incremental Product Development. Four essays on activities, resources, and actors, Norvegian School of Management, Oslo.

Otto Kevin N., Wood Kristin L. (1998) Product Evolution: A Reverse Engineering and Redesign Methodology, Research in Engineering Design, n. 10, pp. 226-243.

Patel Pari, Pavitt Keith (1995) Patterns of Technological Activity: their Measurement and Interpretation, Paul Stoneman (ed.) Handbook of the Economics of Innovation and Technological Change, Blackwell, Oxford, 14-51.

Porter Michael E. (ed.) (1986) Competition in Global Industries, Harvard Business School Press, Boston, MA.

Salvioni Daniela M. (2012) Governance e Risk Management nei mercati globali, Fortuna F. (ed.) Liber Amicorum per Umberto Bertini, F Angeli, Milano, pp. 512-521. 
Salvioni Daniela M. (2010) Intangible Assets and Internal Controls in Global Companies, Symphonya. Emerging Issues in Management (symphonya.unimib.it), n. 2, pp. 39-51.

http://dx.doi.org/10.4468/2010.2.4salvioni

Schmookler Jacob (1966) Invention and Economic Growth, Harvard University Press, Cambridge, MA.

Schumpeter Joseph A. (1934) The Theory of Economic Development: An Inquiry into Profits, Capital, Credit, Interest, and the Business Cycle, Harvard Business Press, Boston, MA.

Schumpeter Joseph A. (1939) Business Cycles. A Theoretical, Historical and Statistical Analysis of the Capitalist Process, McGraw-Hill, New York.

Shenkar Oded (2010) Copycats: How Smart Companies Use Imitation to Gain a Strategic Edge, Harvard Business Press, Boston.

Singh Jagdeep, Singh Harwinder (2009) Kaizen Philosophy: A Review of Literature, Icfai Journal of Operations Management, vol. 8, n. 2, pp. 51-72.

Taiichi Ohno (2007) Lo spirito Toyota, Einaudi, Torino (trad. it. The Toyota Production System).

Tesfaye Helen Gebremeskel, Nguyen Thi Hong Nhung (2012) Incumbent firms and Response to Disruptive Innovation through Value Network Management. Lessons from Eastman Kodak's failure in the digital era, Master of Science in Business Administration, Strategy and Management in International Organizations, Department of Management and Engineering, Linköpings Universitet, Spring.

Trott Paul, Hoecht Andreas (2007) Product Counterfeiting, Non-Consensual Acquisition of Technology and New Product Development: An Innovation Perspective, European Journal of Innovation Management, vol. 10, n. 1, pp. 126-143.

http://dx.doi.org/10.1108/14601060710720582

Tushman Michael, Anderson Philip (1986) Technological Discontinuities and Organizational Environments, Administrative Science Quarterly, vol. 31, n. 3, September, pp. 439-465.

Urban Glen L., Hauser John R. (1993) Design and Marketing of New Products, Prentice Hall, Englewood Cliffs, NJ.

Urban Glen L., Weinberg Bruce, Hauser John R. (1996) Premarket Forecasting of Really-New Products, Journal of Marketing, vol. 60, n. 1, January, pp. 47-60. Abstracted in the Journal of Financial Abstracts, vol. 2, n. 23A, June 1995.

Urban Glen L., Hauser John R., Roberts John H. (1990) Prelaunch Forecasting of New Automobiles: Models and Implementation, Management Science, vol. 36, n. 4, April, pp. 401-421. 